\title{
Grain Yield, Quality and Deoxynivalenol (DON) Contamination of Durum Wheat (Triticum Durum Desf.): Results of National Networks in Organic and Conventional Cropping Systems
}

\author{
Fabrizio Quaranta*1, Tiziana Amoriello ${ }^{2}$, Gabriella Aureli ${ }^{1}$, Andreina Belocchi $^{1}$, \\ Maria Grazia D’Egidio ${ }^{1}$, Mauro Fornara ${ }^{1}$, Sahara Melloni ${ }^{1}$, Ersilio Desiderio ${ }^{1}$ \\ ${ }^{1}$ CRA-QCE - Cereal Quality Research Unit, Via Cassia 176, 00191 Roma, Italy \\ ${ }^{2}$ CRA - Sede Centrale, Via Nazionale 82, 00184 Roma, Italy
}

Received: 14 September 2009. Accepted: 26 July 2010.

\begin{abstract}
This work shows the results of trials carried out over three years (2006-2008) within the national networks of durum wheat grown under conventional and organic cropping systems in six representative locations of the main cultivation areas of Italy. The main aspects of grain yield and grain quality were analyzed, particularly assessing the hygienic health status of the grain in relation to the possible presence of deoxynivalenol (DON) contamination. DON is considered the most common trichothecene mycotoxin found in the wheat grain, causing significant reductions in grain yield and adverse effects for human or animal consumption.

In the studied period the average grain yields were quite interesting both in conventional samples $\left(5.85 \mathrm{t} \mathrm{ha}^{-1}\right)$ and in organic ones $\left(4.91 \mathrm{t} \mathrm{ha}^{-1}\right)$. As expected, the organic yields were significantly different(-16\%). However, in the southern locations the same differences were lower $(-5 \%)$, thus emphasizing the limited impact of the higher inputs of the conventional cropping in these environments. The reduced nitrogen input is notoriously the most critical point of organic wheat, because the protein content is the most sensitive parameter of grain quality. The protein content was significantly different among year, fields location and cropping system, but not among their interactions. Grain protein content in organic wheat was lower than in conventional one all over the three years; anyway, differences were somewhat limited (only about $1 \%$ in the southern locations and $0.5 \%$ in central Italy).

Among cultivars no significant differences in the protein content were recorded. Mean levels of DON contamination during the study period were generally lower, with only a sample exceeding the legal limit of $1750 \mathrm{ppb}$.

Among the main factors, year and location (and their interaction) had a strong influence on DON contamination, accounting for $75 \%$ of the observed variability. DON levels in 2008 at Papiano-PG were dramatically high; the strong influence of the year-location interaction may be due to this fact. Cropping system and cultivar, although significant, had a low influence; however, their interaction accounted for $13 \%$ of total variance. Cropping system - location interaction accounted for $5 \%$ of the total variability. Very low levels of DON were detected in the southern locations with both cropping systems; the lower levels were recorded in organic wheat samples. In the central Italy areas DON could represent a potential hazard, but even in these organically cropped environments wheat gave the best results. Lower concentrations of DON were detected in organic wheat samples, either in less favourable years for the occurrence of Fusarium (2006 and 2007) and in the more favourable one (2008). Regarding the role of the varietal choice, Creso revealed to be the less susceptible to DON contamination, probably as it is the best adapted to the areas of the Central Italy, where Fusarium is more widespread.
\end{abstract}

Key-words: conventional, deoxynivalenol (DON), durum wheat, yield, organic, protein content.

\section{Introduction}

Durum wheat (Triticum durum Desf.) is the most widespread crop in Italy (approximately ha 1.60 millions) with an important and growing quota of organic cropping system. Howev- er, durum wheat also results susceptible to infection by phytopathogenic fungi with especially in several species of genus Fusarium which cause Fusarium head blight (FHB), (Parry et al., 1995), a significant disease of small-grain cere-

* Corresponding Author: Tel.: +39 06 3295705; Fax: +39 06 3319215. E-mail address: fabrizio.quaranta@entecra.it 
als widely distributed in the temperate zones of the world (Creppy, 2002).

Furthermore, various species of this genus of fungi can produce toxic secondary metabolites, as mycotoxins, which accumulate in the grain. This fact can cause significant yield reduction and low quality of grain, leading to important economic losses. In addition, given the quantities of cereal-derived food consumed daily, the occurrence of mycotoxins in grains constitutes an important food safety issue (Boutigny and Forget, 2008). Field surveys indicate that deoxynivalenol (DON or "vomitoxin") and its derivatives are the most frequently encountered mycotoxins in FHB disease of wheat throughout the European countries, mainly produced by F. graminearum and F. culmorum (Bottalico and Perrone, 2002). These toxic compounds, belonging to trichothecenes group of mycotoxins, mostly act as potent inhibitors of eukaryotic protein synthesis (Rocha et al., 2005), therefore both concerning human and animal health (Bennett and Klich 2003). In cereals the maximum level of DON in raw material is $1750 \mathrm{ppb}$ and the temporary Tolerable Daily Intake (TDI) is $1 \mu \mathrm{g} / \mathrm{kg} \mathrm{BW}$ (SCF/ 27 february 2002; Reg. CE n. 1881/2006).

The main inoculum source of $F$. graminearum is host debris, such as old corn stocks, ears and stubble, which all can promote the mold infection during the subsequent cropping season (Trenholm, 1989).

Given the well-known difficulty in removing DON and other trichothecenes during post-harvesting stages mostly considering the partial persistence of these toxins in the milling and baking processes, at present, the most efficient risk management of mycotoxins occurrence in food mainly regards the actions of prevention in field. It has been shown that some cultural practices (ploughing, tillage, preceding crop and choice of cultivar) can contribute to the occurrence of FHB (Champeil et al., 2004), while correct agronomic practices are generally used with the aim to reduce the risk of contamination of wheat (Champeil et al., 2004; Edwards, 2004).

The degree of resistance to mould infection at various stages of plant development is different among cultivars. In fact some cultivars show high susceptibility at the flowering stage while other ones at the milk or soft dough stages (Schroeder and Christensen, 1963). Infection is favoured by warmth and prolonged surface wetness. Temperatures of $15-35^{\circ} \mathrm{C}$ splashing or winddriven rain leading on dispersal of spores and persistent wetness ( $>48-60$ hours) of wheat spikes everyone favour mould infection (Sutton, 1982). The content of mycotoxins is depending on various factors as kind of fungi involved and environmental conditions occurring from infection to harvesting phase. Moreover, it is known the influence of yearly climatic conditions, also the importance of previous crop rather than cultivar resistance on level of contamination by mycotoxins.

The increasing area of the wheat organic cropping system had feared for a greater presence of DON in foodstuffs because the prohibition of employing the synthetic pesticides for defence. Moreover, lower grain yields and protein content (D'Egidio, 2009), had created uncertainty about the use of organic agricultural techniques for durum wheat.

The reviews of published studies reporting contamination by trichothecenes (especially DON) of conventionally and organically grown cereals are contradictory (Tamm and Thurig, 2002). It seems, actually, that more recent data and systematic comparisons performed on field trials under scientifically controlled conditions lead to a more favourable situation for organic cereals (Rossi et al., 2006). This could be explained by the fact that, in the past, there were numerous organic growers and retailers who were less experienced and not really aware of good agriculture and manufacturing practices (Pussemier et al., 2004).

However recent studies concerning particular safety practices adopted in organic farming systems, show the lower incidence of Fusarium spp. than conventional systems (Edwards, 2009; Vànovà et al., 2008; Pussemier et al., 2006). Previous studies comparing organic to conventional wheat either failed to identify significant differences between the two practices (Berleth, 1998; Malmauret et al., 2002; Cirillo et al., 2003; Jestoi et al., 2004) or have detected significantly lower levels of DON in organic samples (Doll et al., 2002; Schollenberger et al., 2002).

Indeed, organic disease management strategies should be mostly preventive and depend on the whole system approach, with particular attention to maintenance of soil health which represents a central component of any strategy (Davies et al., 2002). 
The aim of this study was to evaluate and elucidate the incidence of the sources of variability for yield, protein content and DON contamination in raw durum wheat grown in comparable environments both in organic and conventional cropping systems in Central and Southern Italy over three years.

\section{Materials and methods}

\section{Field trials}

The following six cultivars with different biological cycle ( $\mathrm{E}=$ early; $\mathrm{M}=$ medium; $\mathrm{L}=$ later) are used: Ciccio (E), Simeto (E), Duilio (E), Iride (ME), Claudio (M) and Creso (L). Samples of raw material came from several experimental fields relating to conventional and organic national networks (Desiderio et al., 2008 and Quaranta et al., 2008) during the three-year period 2006-2008 in both cropping systems. The following fields selected were representative of durum wheat growing areas, three in Central Italy: Jesi-AN ( $43^{\circ} 31^{\prime} \mathrm{N}$ and $13^{\circ} 15^{\prime} \mathrm{E}$; $80 \mathrm{~m}$ a.s.l.), Pollenza-MC ( $43^{\circ} 16^{\prime} \mathrm{N} 13^{\circ} 21^{\prime} \mathrm{E}$; $250 \mathrm{~m}$ a.s.l. $)$, Papiano-PG (42 $57^{\prime} \mathrm{N}$ and $12^{\circ} 20^{\prime} \mathrm{E}$; $170 \mathrm{~m}$ a.s.l.); and three in South Italy: Campobasso-CB (41 ${ }^{\circ} 34^{\prime} \mathrm{N}$ and $14^{\circ} 39^{\prime} \mathrm{E}$; $700 \mathrm{~m}$ a.s.l.), Foggia- FG (41 ${ }^{\circ} 32^{\prime} \mathrm{N}$ and $15^{\circ} 43^{\prime} \mathrm{E} ; 70 \mathrm{~m}$ a.s.l.) and S.Stefano Quisquina-AG $\left(37^{\circ} 37^{\prime} \mathrm{N}\right.$ and $13^{\circ} 29^{\prime} \mathrm{E} ; 250 \mathrm{~m}$ a.s.l.).

Preceding crops were the same in Jesi-AN, Pollenza-MC and S. Stefano Quisquina-AG fields, both for organic and conventional samples, whereas in Papiano-PG, Campobasso and Foggia-FG they were different, depending on the cropping system (Table 1). Conventional cropping system in these same locations soil hosted previous year's crop residues (barley, sunflower and fallow with gramineous weeds) which could contribute to Fusarium infection (Pereyra and Dill-Macky, 2008).

Only for the conventional production system the amount of nitrogen inputs ranged between a minimum of $50-80 \mathrm{~kg} \mathrm{~N}^{-1}$ in the South locations and a maximum of about $200 \mathrm{~kg} \mathrm{~N} \mathrm{ha}^{-1}$ in Centre locations. Instead, no treatment was applied for the organic system and in some locations organic manures were used.

Herbicides were used for weeds control in conventional crop while the organic one has relied to the usual good agronomical practices, such as crop rotation and mechanical weed control (weed harrowing).

A randomized complete block experimental design with three or four replications was used at each site. The plot size was $10 \mathrm{~m}^{2}$ and the distance between the rows was $17 \mathrm{~cm}$. The grain samples from single replicates were grouped and the final pooled sample was employed for laboratory analyses.

\section{Analytical determinations}

Agronomic data were collected throughout the course of the experiment. The traits measured on each plot included: days to heading, crop density (spikes $\mathrm{m}^{-2}$ ), test weight, 1000 kernels weights (TWK), grain yield and grain protein content.

The quality characterization has been performed by the main used chemical and technological analyses: test weight and protein content were evaluated by Near Infrared Transmittance (NIT) technology employing the Infratec ${ }^{\mathrm{TM}}$ 1241 Grain Analyzer FOSS, (wavelength range: 570-1100 nm). Data Integration was carried out by FOSS DataLogger and DataLink software.

The whole milled samples (Cyclotec-PBI,

Table 1. It gives information about locations, crops planted previous to wheat and date of sowing both conventional and organic wheat.

\begin{tabular}{|c|c|c|c|c|c|c|c|c|c|c|c|c|c|}
\hline \multirow{3}{*}{\multicolumn{2}{|c|}{ LOCATIONS }} & \multicolumn{4}{|c|}{2006} & \multicolumn{4}{|c|}{2007} & \multicolumn{4}{|c|}{2008} \\
\hline & & \multicolumn{2}{|c|}{ preceding crop } & \multicolumn{2}{|c|}{ data of sowing } & \multicolumn{2}{|c|}{ preceding crop } & \multicolumn{2}{|c|}{ data of sowing } & \multicolumn{2}{|c|}{ preceding crop } & \multicolumn{2}{|c|}{ data of sowing } \\
\hline & & ORG & CONV & ORG & CONV & ORG & CONV & ORG & CONV & ORG & CONV & ORG & CONV \\
\hline & Jesi (AN) & pea & pea & $16 / 12$ & $16 / 12$ & pea & pea & $06 / 11$ & $08 / 11$ & pea & pea & $23 / 11$ & $13 / 11$ \\
\hline & Pollenza (MC) & tomato & tomato & $12 / 01 / 07$ & $05 / 12$ & tomato & tomato & $29 / 11$ & $10 / 11$ & tomato & tomato & $03 / 12$ & 28/11. \\
\hline & Papiano (PG) & tomato & sunflower & $11 / 11$ & $10 / 11$ & field bean & sunflower & $07 / 11$ & $15 / 11$ & field bean & sunflower & $05 / 11$ & $7 / 11$ \\
\hline \multirow{3}{*}{$\begin{array}{l}\bar{F} \\
\text { D }\end{array}$} & Campobasso (CB) & sulla & barley & $15 / 11$ & $15 / 11$ & sulla & sunflower & $30 / 10$ & $31 / 10$ & sulla & sunflower & $13 / 11$ & $29 / 11$ \\
\hline & Foggia (FG) & chickpea & fallow & $03 / 12$ & $01 / 12$ & chickpea & fallow & $20 / 12$ & $04 / 12$ & chickpea & fallow & $21 / 12$ & $26 / 11$ \\
\hline & S. Stefano Q. (AG) & clover & clover & $22 / 12$ & $23 / 12$ & clover & clover & $05 / 12$ & $05 / 12$ & clover & clover & $15 / 12$ & $05 / 12$ \\
\hline
\end{tabular}


mesh size: $0.5 \mathrm{~mm}$ ) were employed for DON analysis using the enzyme-linked immunosorbent assay (test ELISA - kit Ridascreen ${ }^{\circledR}$, RBiopharm) having limit of detection of $18.5 \mathrm{ppb}$ and recovery value between 85 and $110 \%$. Duplicate analyses were carried out with a rate of coefficient of variation $(\mathrm{CV}) \leq 10 \%$.

\section{Statistical analysis}

Grain yield and protein content. Two global statistical models of analysis of variance were used to study the four factors influence on grain yield and protein content. We assumed the two response variables $\mathrm{Y}_{\mathrm{A}}=$ Yield and $\mathrm{Y}_{\mathrm{B}}=$ Protein have a Normal distribution. The two models considered four factors (cultivar, cropping system, year, field location) with their interaction.

$$
\begin{gathered}
\mathrm{Y}_{\mathrm{A}, \mathrm{B}}=\alpha_{0}+\tau_{\mathrm{i}}+\gamma_{\mathrm{j}}+\delta_{\mathrm{l}}+\zeta_{\mathrm{k}}+ \\
\tau_{\mathrm{i}} \cdot \gamma_{\mathrm{j}}+\tau_{\mathrm{i}} \cdot \delta_{1}+\tau_{\mathrm{i}} \cdot \zeta_{\mathrm{k}}+\gamma_{\mathrm{j}} \cdot \delta_{1}+\gamma_{\mathrm{j}} \cdot \zeta_{\mathrm{k}}+\delta_{1} \cdot \zeta_{\mathrm{k}}+\varepsilon_{\mathrm{ijlk}}
\end{gathered}
$$

where $\tau_{\mathrm{i}}=$ cultivar; $\mathrm{i}=1, \ldots, 6(1=$ Ciccio, $2=$ Claudio, 3 = Creso, $4=$ Duilio, $5=$ Iride, $6=$ Simeto);

$\gamma_{\mathrm{j}}=$ cropping system; $\mathrm{j}=1,2$ ( 1 = conventional, 2 = organic);

$\delta_{1}=$ year $1=1,2,3 ;(1=2006,2=2007,3=2008) ;$ $\xi_{\mathrm{k}}=$ field location; $\mathrm{k}=1, \ldots, 6(1=$ Jesi, $2=$ Pollenza, 3 = Papiano, 4 = Campobasso, $5=$ Foggia, $6=\mathrm{S}$. Stefano Quisquina);

$\alpha_{0}=$ mean effect common to all observations

$\varepsilon_{\mathrm{ijlk}}=$ error component.

Deoxynivalenol contamination. Generalized linear models (GLM) were used to test significant effects of deoxynivalenol contamination caused by many factors and all their two-way interactions. We assume the response variable $\mathrm{Y}$ (DON) has a Poisson distribution and the logarithm of its expected value $\mathrm{E}(\mathrm{Y})$ can be modelled by a linear combination of unknown parameters. Poisson regression models are GLM with the logarithm as the canonical link function and the Poisson distribution function. The considered model is:

$$
\begin{aligned}
& \log (\mathrm{DON})=\beta_{0}+\tau_{i}+\gamma_{\mathrm{j}}+\delta_{1}+\zeta_{\mathrm{k}}+\tau_{\mathrm{i}} \cdot \gamma_{j} \\
& \quad+\gamma_{i} \cdot \delta_{1}+\gamma_{\mathrm{i}} \cdot \zeta_{\mathrm{k}}+\gamma_{\mathrm{j}} \cdot \delta_{1}+\gamma_{\mathrm{j}} \cdot \zeta_{\mathrm{k}}+\delta_{1} \cdot \zeta_{\mathrm{k}}+\varepsilon_{\mathrm{ijlk}}
\end{aligned}
$$

where $\beta_{0}=$ mean effect common to all observations.

The goodness of fit of GLM model can be based on the deviance statistic, approximated by a chi-square distribution. We use the log-likeli- hood value to measure the goodness of fit of the regression models.

The year and field location terms of these models (grain yield, protein content, DON) were estimated as fixed effects being the levels of the factors linked to this specific experiment and selected with the purpose of comparing the effects of the levels to one another.

The interactions between factors were introduced for both their high statistic significance and physical meaning. The introduction of interactive terms allows to understand if the only main effects (differences between Y means calculated on different levels of each individually considered factor) are important or if interaction effects exist (main effect variations of a factor between the levels of one or more levels of another factor). The existence of these interactions can modify or invalidate the inference on the main effects.

All models will test in two steps considering: a) only the four main factors; b) only the main factors resulted significant with the respective two-way interactions.

Weather conditions. All over-the first two years (2006-2007) weather conditions were in accordance with long period average values expected for a typical Mediterranean climate, while in 2008 there was a particularly warm and rainy spring, which caused in some locations of Central and Northern Italy extended lodging, accumulations of plants on the humid soil surface, difficulty to dry before harvesting, moist conditions favourable for formation of both Fusarium macroconidia and ascospores (Sutton, 1982).

Figures $1 a$ and $1 b$ show the average of the monthly values of temperature and rainfall from October to June in two field locations Jesi-AN and S. Stefano Quisquina-AG, each representative of the trend of the weather conditions in Central and Southern areas of Italy, respectively, during the period 2006-2008. Deviations of such mean values from the corresponding long period average are also shown.

Aufhammer et al. (1999) reported that FHB infection severity was generally correlated with the duration of flowering. The spores are disseminated by wind under favourable weather conditions to wheat spikes at flowering time (Mauler-Machnik and Suty, 1997) and after successful infection colonization of the ear pro- 


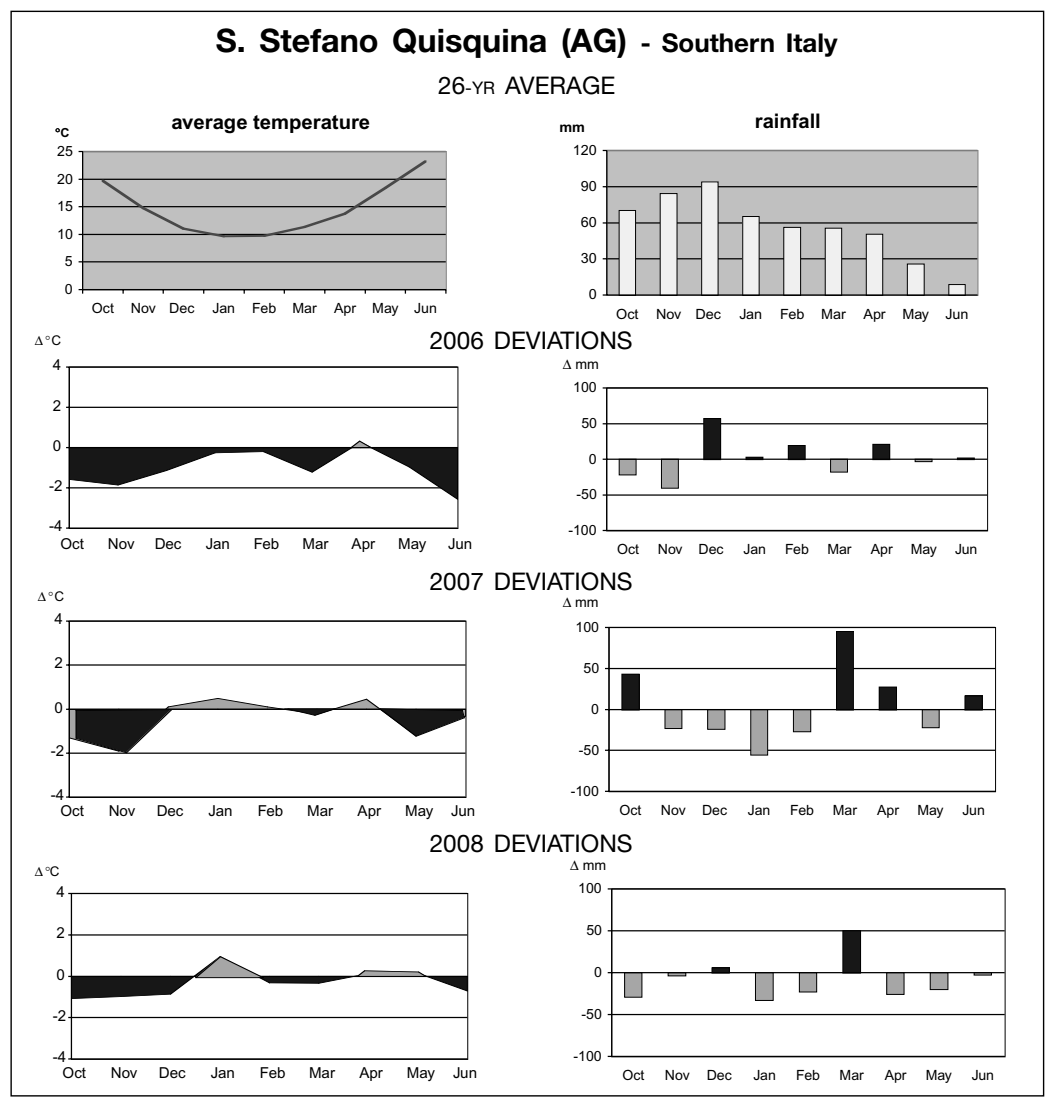

Figure 1a. S. Stefano Q.-AG. Annual difference among monthly average air temperature and total rainfall and the corresponding long period average (1980-2005).

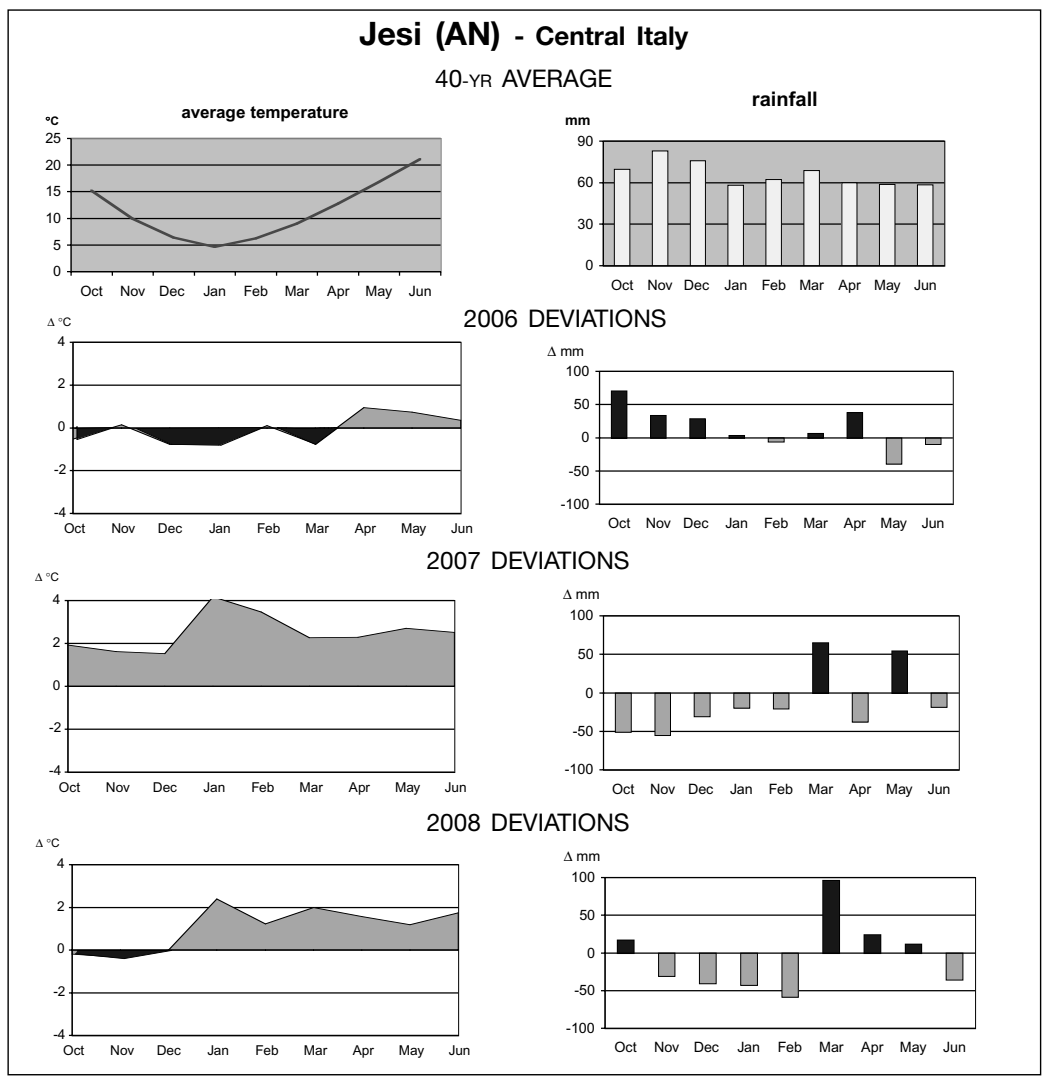

Figure 1b. Jesi-AN. Annual difference among monthly average air temperature and total rainfall and the corresponding long period average. 


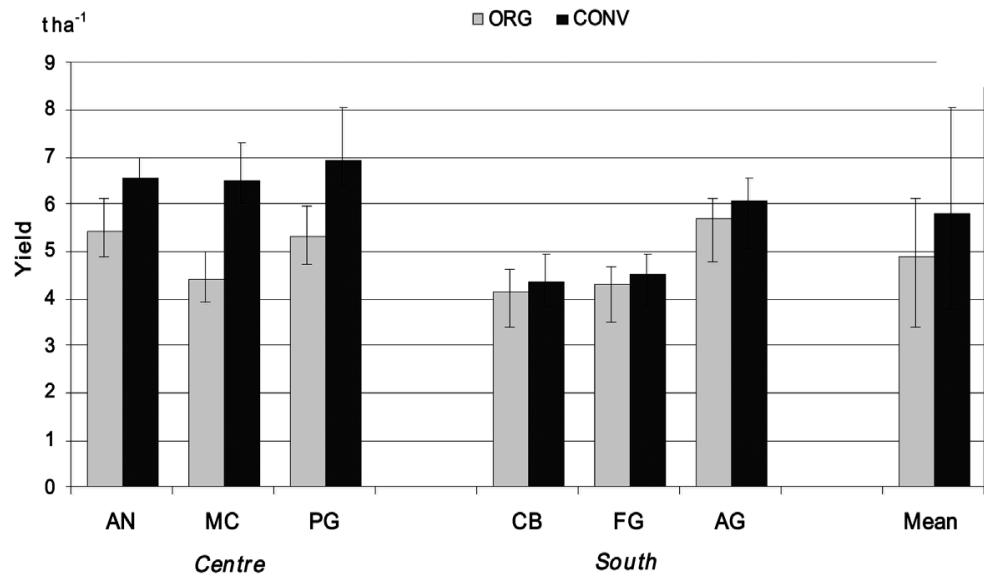

Figure 2. Comparison of national networks in organic and conventional cropping systems. Grain yield ( $\mathrm{t} \mathrm{ha}^{-1}$ at moisture $13 \%$ ): means of the six cultivars in two different agro-climatic areas of Italy. Vertical bars are maximum and minimum values. ceeds until ripening of the crop. This indicated the importance of weather in springtime on the final mycotoxins content of grain at harvest; indeed many studies have associated the occurrence of FHB with weather conditions during heading stage and early kernel development (Pugh et al.,1933; Miller, 1994).

\section{Results and discussion}

\section{Grain yield}

The average grain yields obtained in the three years in six locations reflected the production expectations in different areas of Italy, both for conventional (5.85 tha-1) and organic (4.91 t hacropping system.

The average yield reduction was about $1 \mathrm{t} / \mathrm{ha}$ in organic compared to conventional $(-16 \%)$, this may be considered in line with the expectations of the two different cropping systems: such differences were much more pronounced in the localities of Central Italy, with a deviation of $24 \%$, while they were definitely lower in the southern localities (-5\%) (Fig. 2 and Tab. 2).

Papiano -PG gave the best yields (average of $\left.6.14 \mathrm{t} \mathrm{ha}^{-1}\right)$ during the study period (5.34 $\mathrm{t} \mathrm{ha}^{-1}$ in organic $6.95 \mathrm{t} \mathrm{ha}^{-1}$ in conventional); conversely Foggia -FG gave the lowest average yield $4.44 \mathrm{t} \mathrm{ha}^{-1}$.

Among locations S. Stefano Q-AG recorded the best yields in organic system $\left(5.70 \mathrm{t} \mathrm{ha}^{-1}\right)$. Average yields for organic production were similar both in Central and Southern Italy (5.08 and $4.74 \mathrm{t} \mathrm{ha}^{-1}$, respectively). Differences were much more pronounced in the conventional system, in the two different areas (6.69 in the Centre and $5.01 \mathrm{t} \mathrm{ha}^{-1}$, in the South, respectively), confirming the limited effect of the increasing energy inputs in the areas of Southern Italy.

The statistical analysis allowed to quantify the incidence of the sources (all factors) of variability for grain yield.

The analysis of variance was carried out in

Table 2. Comparison of national networks in organic and conventional cropping systems. Grain yield ( $\mathrm{t}$ ha ${ }^{-1}$ at moisture $13 \%)$ of six common cultivars in two areas of Italy: means and standard deviations of six locations during three years of trials.

\begin{tabular}{lcccccc}
\hline Cultivar & \multicolumn{2}{c}{ Central Italy } & \multicolumn{2}{c}{ Southern Italy } & \multicolumn{2}{c}{ General means } \\
\cline { 2 - 7 } & ORG & CONV & ORG & CONV & ORG & CONV \\
\cline { 2 - 7 } Ciccio & $4.64 \pm 1.80$ & $6.36 \pm 1.30$ & $4.96 \pm 0.96$ & $5.21 \pm 1.40$ & $4.80 \pm 1.50$ & $5.79 \pm 1.51$ \\
Simeto & $4.69 \pm 1.66$ & $6.25 \pm 0.91$ & $4.81 \pm 0.88$ & $4.66 \pm 1.27$ & $4.75 \pm 1.37$ & $5.45 \pm 1.40$ \\
Duilio & $5.34 \pm 1.47$ & $6.63 \pm 1.15$ & $4.97 \pm 1.15$ & $5.25 \pm 1.32$ & $5.15 \pm 1.37$ & $5.94 \pm 1.46$ \\
Iride & $5.70 \pm 1.49$ & $7.45 \pm 1.17$ & $4.57 \pm 1.27$ & $5.23 \pm 1.40$ & $5.13 \pm 1.54$ & $6.34 \pm 1.75$ \\
Claudio & $5.30 \pm 1.59$ & $7.19 \pm 1.06$ & $4.88 \pm 0.93$ & $5.33 \pm 1.36$ & $5.09 \pm 1.36$ & $6.26 \pm 1.58$ \\
Creso & $4.84 \pm 1.38$ & $6.30 \pm 1.09$ & $4.23 \pm 0.68$ & $4.37 \pm 1.29$ & $4.53 \pm 1.16$ & $5.33 \pm 1.58$ \\
Mean & $5.08 \pm 1.62$ & $6.69 \pm 1.21$ & $4.74 \pm 1.03$ & $5.01 \pm 1.39$ & $4.91 \pm 1.37$ & $5.85 \pm 1.54$ \\
\hline
\end{tabular}


Table 3. Analysis of variance for grain yield.

\begin{tabular}{|c|c|c|c|}
\hline & Deviance & Factor deviance / total deviance (\%) & p-value \\
\hline Total & 65.19 & & $* * *$ \\
\hline Cultivar & 0.001 & 0 & ns \\
\hline Year & 0.67 & 1 & ns \\
\hline Location & 16.72 & 26 & $* *$ \\
\hline Cropping system & 47.79 & 73 & $* * *$ \\
\hline \multicolumn{4}{|c|}{$2^{\mathrm{ND}}$ MODEL: Yield $=$ location + cropping system + location $*$ cropping system $\left(\mathrm{R}^{2}=0.16\right)$} \\
\hline & Deviance & Factor deviance / total deviance (\%) & p-value \\
\hline Total & 79.23 & & $* * *$ \\
\hline Location & 16.72 & 21 & $* *$ \\
\hline Cropping system & 47.79 & 60 & $* * *$ \\
\hline Location*Cropping system & 14.72 & 19 & $* *$ \\
\hline
\end{tabular}

*** Significant at the 0.0001 probability level

** Significant at the 0.001 probability level.

* Significant at the 0.05 probability level.

$\mathrm{ns}=$ Not significant.

two steps (Table 3): at first we considered only the influence of the four main factors on grain yield $\left(1^{\text {ST }}\right.$ MODEL: Yield = cultivar + year + location + cropping system); then we also considered the interactions between factors resulted significant for the first application (2 ${ }^{\mathrm{ND}}$ MODEL: Yield = location + cropping system + location*cropping system). Cultivar and year factors were not significant, so they were eliminated from the second model. The coefficient of determination $\mathrm{R}^{2}$ is rather low: it ranged from 0.13 to 0.16 . The cropping system factor resulted highly significant: its contribution to the explanation of variability was $73 \%$, up to $79 \%$ taking also into account the interaction with location. It confirms that the most important factor in explaining the production difference is the method of cropping system with a significantly greater grain yield in the conventional production, especially in the localities of Central Italy.

Years were not significant for the grain yield, explaining only $1 \%$ of the total variability.

In central Italy 2006 was particularly critical for organic wheat, with yields lower by $52 \%$ compared to conventional, due to continuous rains which caused a huge leaching of nitrogen. Notoriously this is the weak point for the organic system; in the conventional system this problem may be resolved by means of nitrogen fertilizers inputs in cover.

For the six varieties there were not significant differences although higher yields were ob- tained from Iride, Claudio and Duilio in both cropping systems, as Creso showed the lowest ones.

\section{Protein content}

The analysis of variance was carried out with two steps (Table 4): at first we only considered the influence of the four main factors on grain yield $\left(1^{\text {ST }}\right.$ MODEL: Protein $=$ cultivar + year + location + cropping system); then we also considered the interactions between factors resulted significant for the first application $\left(2^{\mathrm{ND}}\right.$ MODEL: Protein = year + location + cropping system + year*location + year*cropping system + location*cropping system). Cultivar factor was not significant, so it was eliminated by the model. Even in this case, the coefficient of determination $\mathrm{R}^{2}$ is rather low: it ranged from 0.17 to 0.18 . Cropping system, location and year were the only three factors significantly affecting the grain protein content, whereas the cultivar factor resulted negligible. Location and cropping system had the same weight (their contribution to the explanation of variability was $35 \%$ and $37 \%$, respectively); the year role was slightly lower $(24 \%)$. No interaction resulted significant.

The most critical point of organic cropping system is the reduced nitrogen input to crops. Anyway, organic grain protein content recorded during the trials was only about $0.5 \%$ in the central area and $1.0 \%$ in the southern one lower than in conventionally cropped wheat (Fig. 3 ); thus, organic system allows to obtain good 
Table 4. Analysis of variance for protein content.

$3^{\mathrm{RD}}$ MODEL: Protein = cultivar + year + location + cropping system $\left(\mathrm{R}^{2}=0.17\right)$

\begin{tabular}{|c|c|c|c|}
\hline & Deviance & Factor deviance / total deviance (\%) & $\mathrm{p}$-value \\
\hline Total & 64.48 & & $* * *$ \\
\hline Cultivar & 1.93 & 3 & ns \\
\hline Year & 15.60 & 24 & $* *$ \\
\hline Location & 22.82 & 35 & $* * *$ \\
\hline Cropping system & 24.13 & 37 & $* * *$ \\
\hline
\end{tabular}

$4^{\mathrm{TH}}$ MODEL: Protein $=$ year + location + cropping system + year*location + year*cropping system + location*cropping system $\left(\mathrm{R}^{2}=0.18\right)$

\begin{tabular}{lccc}
\hline & Deviance & Factor deviance / total deviance (\%) & p-value \\
\hline Total & 66.22 & & $* * *$ \\
Year & 15.60 & 24 & $* *$ \\
Location & 22.82 & 35 & $* * *$ \\
Cropping system & 24.13 & 36 & $* * *$ \\
Year*Location & 0.31 & 0 & $\mathrm{~ns}$ \\
Year*Cropping system & 2.61 & 4 & $\mathrm{~ns}$ \\
Location*Cropping system & 0.74 & 1 & $\mathrm{~ns}$ \\
\hline
\end{tabular}

*** Significant at the 0.0001 probability level.

** Significant at the 0.001 probability level.

* Significant at the 0.05 probability level.

$\mathrm{ns}=$ Not significant.

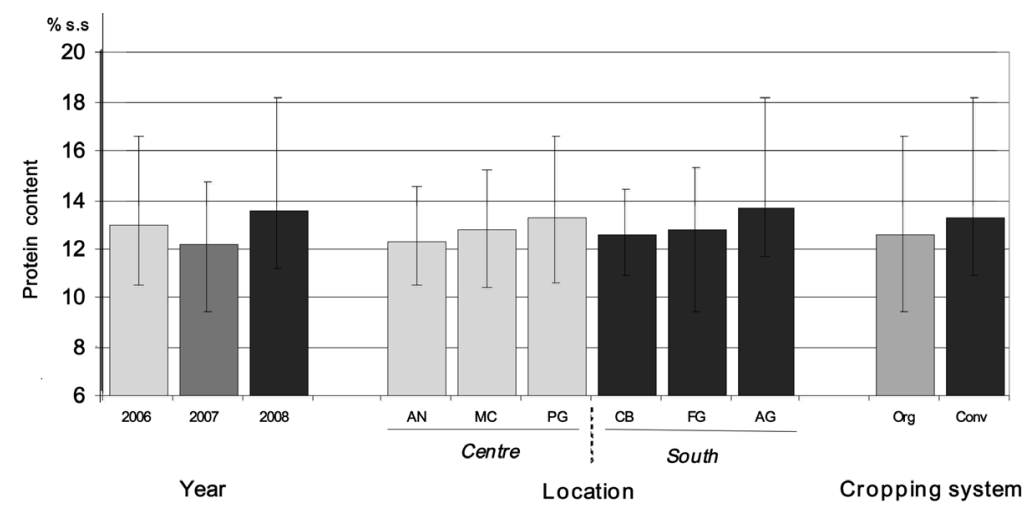

Figure 3. Grain protein content $(13 \% \mathrm{DM})$ : means of the main factors of variability. Vertical bars are maximum and minimum values.

results from the point of view of grain protein content.

Protein content is inversely affected by lower yields obtained in organic system and in any case by climatic conditions influencing the absorption of available nitrogen. There was a widespread variability between locations and years (Fig. 3), whereas the tested varieties showed greater homogeneity, particularly the differences between organically and conventionally cropped plot for any cultivar were never significant, both for to Central and Southern Italy (Tab. 5). Simeto and Creso showed a slightly better ability in nitrogen absorption, on the contrary Iride seemed less efficient, both in con- ventional $(12.6 \% \mathrm{DM})$ and, especially, in organic system $(11.9 \% \mathrm{DM})$.

\section{Deoxynivalenol contamination}

The mean levels of DON contamination attributable to the main factors (years, location and cropping system)are represented in Figure 4.

Mean levels of DON contamination were generally lower with a single sample during the three year-period exceeding the legal limit of 1750 ppb (Reg. CE 1881/2006), with special regard to the organic durum wheat over the years (2006-2007) characterized by lower Fusarium spp contamination than the other one (2008) (Fig. 5). 


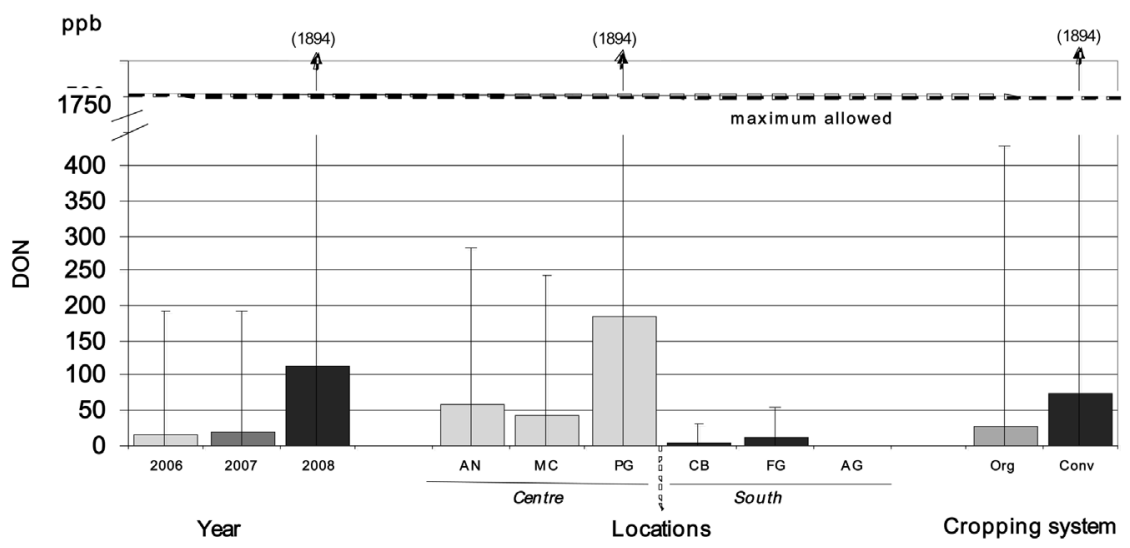

Figure 4. DON concentration (ppb): means of the main factors of variability. Vertical bars are maximum and minimum values.

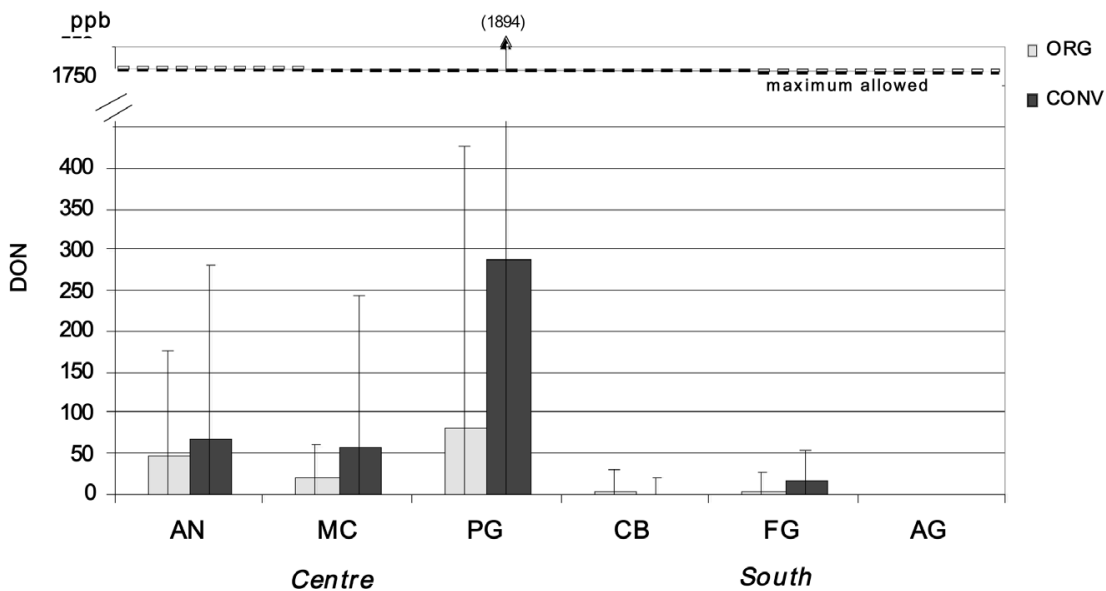

Figure 5. DON concentration (ppb): comparison of organic an conventional cropping system during the three-year period. Vertical bars are maximum and minimum values.
Concerning the six fields, levels of DON contamination showed higher mean values in central areas than in southern ones where the climatic conditions are characterized by lower rainfalls and low atmospheric relative humidity (Fig. 6). Particularly, a lot of samples coming from the fields of the South showed a level of contamination near to the detection limit of the analytical method employed, while negative re- sults were always obtained in location of S. Stefano Quisquina -AG even during the critical year 2008.

Widely positive results throughout the years even in Campobasso -CB and Foggia -FG were obtained (Fig. 7).

Concerning the susceptibility of the six cultivars to the mycotoxin occurrence, one of them

(Creso) showed slightly lower mean values

Table 5. Protein content (\% DM) of six common cultivars: means and standard deviations of six locations for each year of trials. Comparison of national networks in organic and conventional cropping systems.

\begin{tabular}{lcccccc}
\hline \multirow{2}{*}{ Cultivar } & \multicolumn{2}{c}{ Central Italy } & \multicolumn{2}{c}{ Southern Italy } & \multicolumn{2}{c}{ General means } \\
\cline { 2 - 6 } & ORG & CONV & ORG & CONV & ORG & CONV \\
\hline Ciccio & $12.9 \pm 1.6$ & $12.8 \pm 0.9$ & $12.2 \pm 0.9$ & $12.6 \pm 1.0$ & $12.5 \pm 1.4$ & $12.7 \pm 1.0$ \\
Simeto & $13.4 \pm 1.7$ & $13.7 \pm 0.8$ & $12.8 \pm 0.9$ & $14.0 \pm 1.5$ & $13.1 \pm 1.4$ & $13.8 \pm 1.3$ \\
Duilio & $12.1 \pm 1.1$ & $13.2 \pm 1.0$ & $12.6 \pm 0.7$ & $13.5 \pm 1.0$ & $12.3 \pm 1.0$ & $13.3 \pm 1.0$ \\
Iride & $11.6 \pm 1.0$ & $12.4 \pm 0.7$ & $12.3 \pm 1.4$ & $12.8 \pm 1.2$ & $11.9 \pm 1.3$ & $12.6 \pm 1.0$ \\
Claudio & $12.4 \pm 1.3$ & $12.8 \pm 0.7$ & $12.5 \pm 1.0$ & $13.4 \pm 1.2$ & $12.5 \pm 1.2$ & $13.1 \pm 1.1$ \\
Creso & $12.8 \pm 1.1$ & $13.3 \pm 0.9$ & $13.5 \pm 0.9$ & $14.5 \pm 1.6$ & $13.2 \pm 1.1$ & $13.9 \pm 1.5$ \\
Mean & $12.5 \pm 1.5$ & $13.0 \pm 0.9$ & $12.6 \pm 1.1$ & $13.5 \pm 1.4$ & $12.6 \pm 1.3$ & $13.3 \pm 1.2$
\end{tabular}



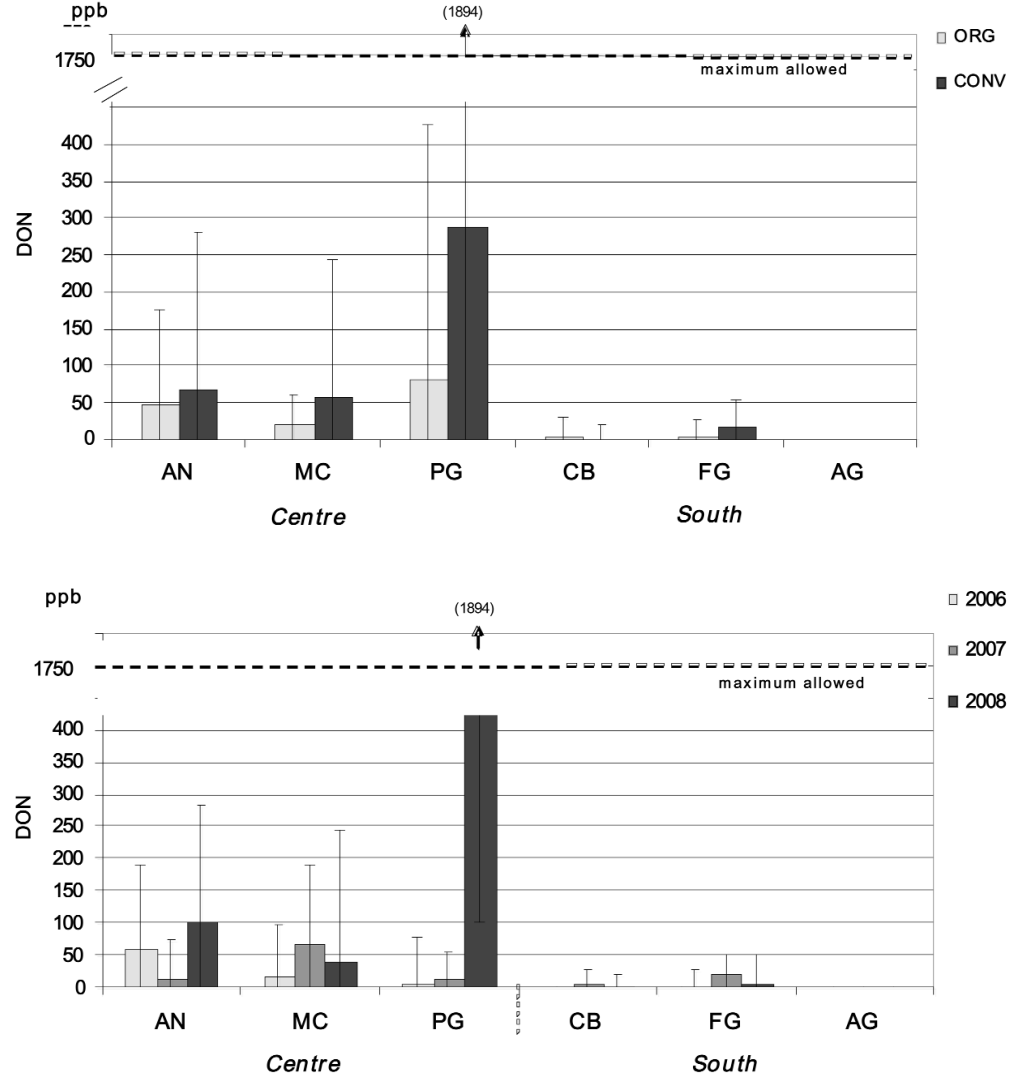

Figure 6. DON concentration (ppb): means of six cultivars grown under organic and conventional cropping system in six locations of Central and Southern Italy. Vertical bars are maximum and minimum values.
Figure 7. DON concentration (ppb): means of three years in six locations of Central and Southern Italy. Vertical bars are maximum and minimum values.
Table 6. Deviance, Log-likelihood, $\chi^{2}$ values and p-value from GLM regression for DON.

\begin{tabular}{lrll}
\hline Deviance & 24725 & & \\
Log-likelihood & 39450 & & \\
$\chi_{\text {global }}^{2}$ & 40997 & $\operatorname{Pr}>\chi^{2}$ & $* * *$ \\
$\chi_{\text {cultivar }}^{2}$ & 20 & $\operatorname{Pr}>\chi_{\text {cultivar }}^{2}$ & $* * *$ \\
$\chi_{\text {location }}^{2}$ & 473 & $\operatorname{Pr}>\chi_{\text {location }}^{2}$ & $* * *$ \\
$\chi_{\text {year }}^{2}$ & 68 & $\operatorname{Pr}>\chi_{\text {year }}^{2}$ & $* * *$ \\
$\chi_{\text {cropping system }}^{2}$ & 20 & $\operatorname{Pr}>\chi_{\text {crop }}^{2}$ & $* * *$ \\
$\chi_{\text {cultivar*location }}^{2}$ & 0 & $\operatorname{Pr}>\chi_{\text {cultivar*location }}^{2}$ & $\mathrm{~ns}$ \\
$\chi_{\text {cultivar*year }}^{2}$ & 21 & $\operatorname{Pr}>\chi_{\text {cultivar*year }}$ & $* *$ \\
$\chi_{\text {cultivar*cropping system }}^{2}$ & 168 & $\operatorname{Pr}>\chi_{\text {cultivar*crop }}^{2}$ & $* * *$ \\
$\chi_{\text {location*year }}^{2}$ & 473 & $\operatorname{Pr}>\chi_{\text {location*year }}^{2}$ & $* * *$ \\
$\chi_{\text {location*cropping system }}^{2}$ & 70 & $\operatorname{Pr}>\chi_{\text {location*crop }}^{2}$ & $* * *$ \\
$\chi_{\text {year*cropping system }}^{2}$ & 20 & $\operatorname{Pr}>\chi_{\text {year*crop }}^{2}$ & $* *$ \\
\hline
\end{tabular}

of contamination (Fig. 8 and Tab. 7 and 8). Creso was less susceptible to DON, as reported by Balmas et al., 1999, also because it showed to be more suitable for the environments of the central Italy where Fusarium contaminations are frequent.

Table 6 shows the GLM analysis for two cropping systems and six cultivars of durum wheat at six locations during the period 20062008. All considered factors and their interactions were all significant with the exception of the cultivar*location interaction. The results indicated that most of the variability in DON con-

Table 7. DON concentration (ppb) of six common cultivars: means and standard deviations of six locations for each year of trials. Comparison of national networks in organic and conventional cropping systems.

\begin{tabular}{lcccccc}
\hline & Cultivar & 2006 & & & 2007 & 2008 \\
\cline { 2 - 6 } & ORG & CONV & ORG & CONV & ORG & CONV \\
\hline Ciccio & $11 \pm 17$ & $13 \pm 31$ & $5 \pm 12$ & $17 \pm 28$ & $39 \pm 62$ & $189 \pm 401$ \\
Simeto & $4 \pm 9$ & $42 \pm 77$ & $14 \pm 22$ & $45 \pm 46$ & $61 \pm 105$ & $212 \pm 354$ \\
Duilio & $29 \pm 72$ & $25 \pm 61$ & $9 \pm 13$ & $55 \pm 71$ & $87 \pm 169$ & $370 \pm 755$ \\
Iride & $0 \pm 0$ & $17 \pm 30$ & $18 \pm 24$ & $42 \pm 54$ & $98 \pm 148$ & $106 \pm 230$ \\
Claudio & $3 \pm 8$ & $22 \pm 40$ & $0 \pm 0$ & $33 \pm 50$ & $58 \pm 77$ & $84 \pm 164$ \\
Creso & $5 \pm 11$ & $9 \pm 22$ & $3 \pm 8$ & $13 \pm 22$ & $13 \pm 58$ & $40 \pm 79$ \\
Mean & $9 \pm 30$ & $21 \pm 46$ & $8 \pm 16$ & $34 \pm 47$ & $64 \pm 106$ & $167 \pm 383$ \\
\hline
\end{tabular}


Table 8. DON concentration (ppb): means and standard deviations of three-year period of six common cultivars in the six locations of trials. Comparison of national networks in organic and conventional cropping systems.

\begin{tabular}{llccccr}
\hline Cultivar & \multicolumn{2}{c}{ Central Italy } & \multicolumn{2}{c}{ Southern Italy } & \multicolumn{2}{c}{ General means } \\
\hline & ORG & CONV & ORG & CONV & ORG & CONV \\
\hline Ciccio & $36 \pm 46$ & $136 \pm 309$ & $0 \pm 0$ & $9 \pm 18$ & $18 \pm 38$ & $73 \pm 235$ \\
Simeto & $50 \pm 80$ & $194 \pm 262$ & $2 \pm 7$ & $6 \pm 16$ & $26 \pm 64$ & $100 \pm 214$ \\
Duilio & $80 \pm 136$ & $295 \pm 572$ & $3 \pm 9$ & $5 \pm 13$ & $41 \pm 106$ & $150 \pm 443$ \\
Iride & $70 \pm 117$ & $104 \pm 107$ & $6 \pm 11$ & $7 \pm 13$ & $39 \pm 92$ & $55 \pm 135$ \\
Claudio & $41 \pm 62$ & $89 \pm 122$ & $0 \pm 0$ & $4 \pm 10$ & $20 \pm 50$ & $46 \pm 100$ \\
Creso & $24 \pm 44$ & $35 \pm 61$ & $6 \pm 10$ & $6 \pm 16$ & $15 \pm 35$ & $21 \pm 48$ \\
Mean & $50 \pm 90$ & $142 \pm 311$ & $3 \pm 8$ & $6 \pm 15$ & $27 \pm 69$ & $74 \pm 232$ \\
\hline
\end{tabular}

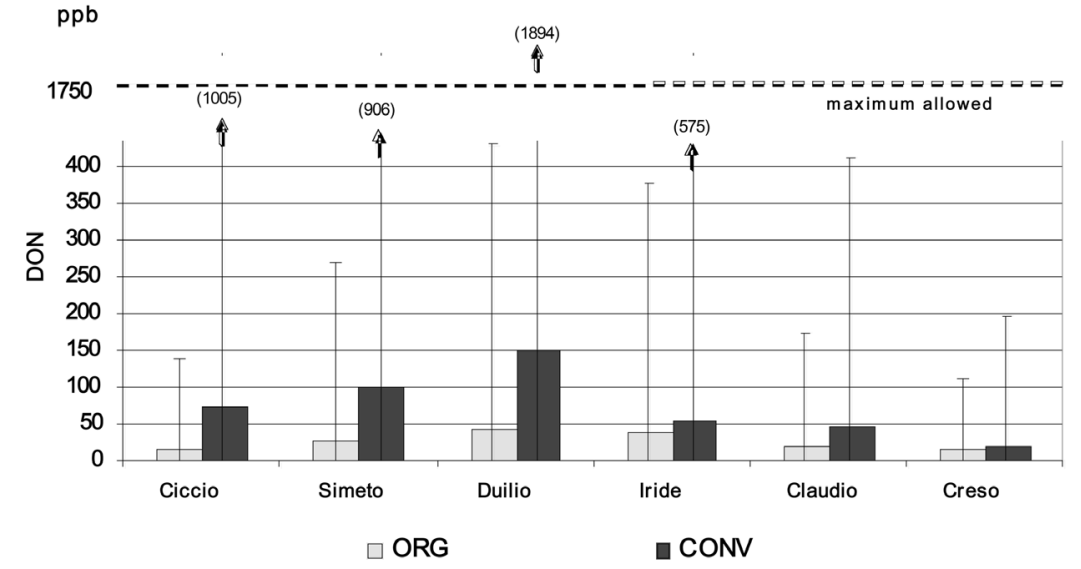

Figure 8. DON concentration (ppb): means of six cultivars grown under organic and conventional cropping systems. Vertical bars are maximum and minimum values. tamination was due to location: considering only the simple effects, over $35 \%$ of the variability could be attributed to location factor. DON concentration in Central Italy locations were higher than in the Southern ones. The variability highly increased considering also its interaction with year (almost 70\%). The influence of the year was due to the different behaviour of 2008 in comparison with the other two years: the mean value of DON during 2008 was 116 ppb, whereas 21 ppb during 2007 and 15 ppb during 2006.

Cropping system and cultivar, although significant, had a low influence; however, their interaction accounted for $13 \%$ of total variance. Cropping system*location interaction accounted for $5 \%$ of the total variability.

\section{Correlations}

In Table 9 the correlations among the different factors are shown. It should be noted the negative low significance $\left(\mathrm{r}=-0.154^{*}\right)$ between the type of biological cycle and yield; pointing out the better results in early cultivars; the kind of cycle results also poorly correlated $\left(\mathrm{r}=0.154^{*}\right)$ to test weight and heavy positively related $(\mathrm{r}=$ $0.399^{* * *}$ ) to thousand-kernel weight. The increasing of yield results also related $(\mathrm{r}=$ $\left.0.391^{* * *}\right)$ to the factor $\mathrm{n}$. spikes $\mathrm{m}^{-2}$ and not related to thousand-kernel weight showing the greater importance of number of seeds produced respect to weight of single kernel.

About the two main parameters of quality, an inverse correlation is confirmed, as is well known in literature, between grain protein content and grain yield $\left(\mathrm{r}=-0.255^{* * *}\right)$; conversely the test weight showed a positive correlation with grain yield $\left(\mathrm{r}=0.193^{* *}\right)$. However, no correlation emerged between cycle and protein content while the correlation was significantly inverse between protein content and thousand kernel weight $\left(\mathrm{r}=-0.183^{* *}\right)$ and test weight $(\mathrm{r}$ $=-0.382 * * *)$. The latter correlation confirms that into stunted kernels the amount of starch decreases in proportion to an increase of protein content, even if that does not imply a higher total protein content.

DON contamination levels are often influ- 
Quaranta F., Amoriello T., Aureli G., Belocchi A., D’Egidio M.G., Fornara M., Melloni S., Desiderio E.

Table 9. Correlations (r) between agronomic traits and DON concentration during the three growing seasons.

\begin{tabular}{lccccccc}
\hline & $\begin{array}{c}\text { Days to } \\
\text { heading }\end{array}$ & Yield & $\begin{array}{c}\text { Protein } \\
\text { content }\end{array}$ & DON & Spikes m $^{-2}$ & $\begin{array}{c}\text { Test } \\
\text { weight }\end{array}$ & $\begin{array}{c}\text { Thousand kernel } \\
\text { weight (TKW) }\end{array}$ \\
\hline Days to heading & 1 & -0.154 & -0.035 & 0.090 & -0.012 & 0.154 & 0.399 \\
$* * *$ \\
Yield
\end{tabular}

enced by cultivar susceptibility to Fusarium infections, which in turn is influenced by the earliness of the cultivar.

Several studies were made about the importance of choosing resistant wheat cultivars to ensure low DON concentration in grain (Koch et al., 2006) also regarding the significance of early and late biological cycle of plants.

Reduced DON values are usually shown by later cultivars, as reported by Balmas et al., (1999).

The results obtained in this study point out clearly the lacking of significant correlation between amount of DON and type of cycle of cultivars (0.090 n.s).

There was also no correlation between production and levels of DON.

Among significant correlations related to the contamination levels of DON, particularly interesting is the increase of DON values with increasing in spikes $/ \mathrm{m} 2\left(\mathrm{r}=0.210^{* *}\right)$ according to Wong et al., 1992; Humphreys et al., 1995.

Moreover, it is confirmed the known positive correlation with protein content $(\mathrm{r}=$ $\left.0.179^{* *}\right)$ and $\mathrm{n}$. ears $\mathrm{m}^{-2}\left(\mathrm{r}=0.210^{* *}\right)$. The increasing of protein amount may be partly related both to the degradation of starchy content by Fusarium and to proteins of the hyphae of fungus causing the consequent increasing of protein content (Boyaciŏglu et al., 1992). It is interesting to note the negative high significant correlation with thousand-kernel weight $(\mathrm{r}=$ $\left.-0.243^{* * *}\right)$ and test weight $\left(\mathrm{r}=-0.476^{* * *}\right)$ both probably due to the direct damaging effect of Fusarium fungi on the kernel.

\section{Conclusions}

The results obtained in these three years of trials for six durum wheat varieties grown under conventional and organic cropping systems in different locations of central and southern Italy revealed some interesting issues.

The average grain yields obtained over the three years with the two cropping methods were statistically different in the six locations. Grain yields were higher in the locations of Central Italy, largely due to the greater results obtained with the conventional system.

In Southern Italy organic crop yields were not different from the results obtained in the same environment with the conventional system, as well as from organic yields recorded in Central Italy.

Grain protein content was significantly higher adopting conventional cropping system; however, a gap of less than $1.0 \%$ compared to organically produced wheat was recorded.

Mean levels of DON contamination were generally lower with only a sample (1894 ppb) during the three year-period exceeding the legal limit of $1750 \mathrm{ppb}$.

Among the examined factors, the effect of location, year and their interactions played a major role. Low presence of DON was confirmed in each location of Southern Italy, in some of them a complete absence of contamination all over the years of trials for both conventional and organic cropping system was detected.

Relevant levels of contamination occurred only in Central Italy, in the most critical year (2008) and for the conventional cropping system. 
Lower concentrations of DON were detected in organic wheat samples, either in less favourable years for the occurrence of Fusarium (2006 and 2007) and in the more favourable one (2008).

Organic cropping system allowed good results not only in the locations where fungal infections is limited (Southern Italy) but even in the locations of Central Italy, which are more exposed to the risks of hazardous fungal pathogens attacks. The low DON contamination under organic cropping system could be explained also taking into account the rotations with non-host Fusarium crops like leguminous. Conversely, in the conventional cropping system is more common to have rotations leaving residues, like barley, sunflower and fallow with gramineous weeds, that could host Fusarium.

The hypothesis of higher levels of DON in durum wheat grown under organic cropping system, based mainly on the consideration of the absence of chemical plant-protection therefore does not seem supported by evidences. In literature a certain difference between organic and conventional systems could be referred to the fungicide application at anthesis (Mesterhazy, 1996). In these trials no fungicide treatments were applied even in conventional cropping system.

Although the choice of the varieties has a reduced influence on the possibility of contamination, some cultivars appear more susceptible to contamination by DON than other ones, likely because they are more suitable to southern Italy areas where the selective pressure of Fusarium is smaller. Moreover the absence of significant correlation between amount of DON and type of cycle of cultivars (0.090 n.s.) was clearly shown.

The results largely confirm the importance of the southern vocational areas for growing durum wheat, which is a primary importance crop for the economy and typicality of such areas.

Given the unpredictability of the climatic seasonal course, the choice of vocated areas and good agronomic practices are the main elements for the containment of Fusarium and relative mycotoxins contamination.

\section{References}

Aufhammer, W., Hermann W., Kubler E. 1999. Fusarium (F. graminearum) infection of ears and toxin concentration of grains of winter wheat, triticale and rye de- pending on cultivars and production intensity. Pflanzenbauwissenschaften, 3:32-39.

Balmas V., Maccaroni M., Santori. A., Corazza L. 1999. Fusariosi della spiga di cereali autunno-vernini: indagine epidemiologica e valutazione della resistenza varietale di frumento duro nell'Italia Centrale. Informatore Fitopatologico, 49:37-41.

Bennett J.W., Klich M. 2003. Mycotoxins. Clinical Microbiology Reviews, 16:497-516.

Berleth M. 1998. Mould spectrum and mycotoxins (deoxynivalenol and ochratoxin A) in grain samples from ecological and integrated cultivated sites. Agribiological Research-Zeitschrift Agrarbiologie Agrikulturchemie Okologie, 51:369-76.

Boyacioglu D., Hettiarachchy N.S., Stack R.W. 1992. Effect of three systemic fungicides on deoxynivalenol (vomitoxin) production by Fusarium graminearum in wheat. Canadian Journal of Plant Science, 72:93-101.

Bottalico A., Perrone G. 2002. Toxigenic Fusarium species and mycotoxins associated with head blight in small-grain cereals in Europe European Journal of Plant Pathology, 108:611-624.

Boutigny A.L., Forget F., Barreau C. 2008. Natural mechanisms for cereal resistanceto the accumulation of Fusarium trichothecenes Eur J Plant Pathology, 121:411-423.

Champeil A., Dore T., Fourbet J.F. 2004. Fusarium head blight: epidemiological origin of the effects of cultural practices on head blight attacks and the production of mycotoxins by Fusarium in wheat grains. Plant Science, 166:1389-1415.

Cirillo T., Ritieni A., Visone M., Cocchieri R.A. 2003. Evaluation of conventional and organic Italian foodstuffs for deoxynivalenol and fumonisins B-1 and B2. J. Agricult. Food Chem., 51:812-831.

Creppy E.F. 2002. Update of survey, regulation and toxic effect of mycotoxins in Europe. Toxicology Letters, 127:19-28.

Davies G., Sumption P., Crockatt M. 2002. Developing improved strategies for pest and disease management in organic vegetable production system in the U.K. In: Brighton Crop Protection Conf.-pest and Disease, Brighton, UK: 547-552.

D'Egidio M.G., Aureli G., Quaranta F., Cecchini C., Melloni S., Moscaritolo S. 2009. Safety and quality of durum wheat from organic crop in Italy. Tecnica Molitoria International Vol 60, 10/A:79-88.

Desiderio E., Belocchi A., D’Egidio M.G., Fornara M., Cecchi V., Cecchini C., Aureli G., Flavoni A. 2008. Risultati della sperimentazione nazionale 2007-08. Varietà di duro alla prova per le semine 2008. L'Informatore Agrario, 64, 34 Suppl.:20-25.

Doll S., Valenta H., Danicke S., Flachowsky G. 2002. Fusarium mycotoxins in conventionally and organically grown grain from Thuringia/Germany. Landbauforschung Volkenrode, 52:91-96.

Edwards S.G. 2004. Influence of agricultural practices on 
Fusarium infection of cereals and subsequent contamination of grain by trichothecene mycotoxins. Toxicology Letters, 153:29-35.

Edwards S.G. 2009. Fusarium mycotoxin content of UK organic and conventional wheat Food Additives and Contaminants. Vol. 26, 4:496-506.

Humphreys J., Cooke B.M., Storey T. 1995. Effects of seedborne Microdochium nivale on establishment and grain yield of winter-sown wheat. Plant Varieties and Seeds, 8:107-117.

Jestoi M., Somma M.C., Kouva M., Veijalainen P., Rizzo A., Ritieni A., Peltonen K. 2004. Levels of mycotoxins and sample cytotoxicity of selected organic and conventional grain-based products purchased from Finnish and Italian markets. Mol. Nutr. Food Res., 48:299-307.

Koch H-J., Pringas C., Maerlaender B. 2006. Evaluation of environmental and management effects on Fusarium head blight infection and deoxynivalenol concentration in the grain of winter wheat. European Journal of Agronomy, 24:357-366.

Malmauret L., Parent-Massin D., Hardy J.L., Verger P. 2002. Contaminants in organic and conventional foodstuffs in France. Food Addit Contam., 19:524-532.

Mauler-Machnik A., Suty A. 1997. New findings on the epidemiology, importance and control of Fusarium ear blight on wheat. Cereal Res. Commun., 25:705-709.

Mesterhazy A. 1996. Fungicide Control of Fusarium Scab and impact on toxin Contamination. Proceeding of a workshop held at Cimmyt "Fusarium Heat Scab: Global Status and Future Prospects”, 13-17 October 1996, El Batan, Mexico, 120-124.

Miller J.D. 1994. Epidemiology of Fusarium ear diseases. In: J.D. Miller, H.L. Trenholm (eds.): Mycotoxins in grain: compounds other than aflatoxin. Eagan Press, St. Paul, Minn., 19-36.

Parry D.W., Jenkinson P., McLeod L. 1995. Fusarium ear blight (scab) in small grain cereals - a review. Plant Pathology, 44:207-238.

Pereyra S.A., Dill-Macky R. 2008. Colonization of the residues of diverse plant species by Gibberella zeae and their contribution to Fusarium Head Blight inoculum. Plant Disease, 2, 5:800-807.

Pugh G.W., Johann H., Dickson J.G. 1933. Factors affecting infection of wheat heads by Gibberalla saubinetii. J. Agric. Res. (Washington, D.C.), 46:771-797.
Pussemier L., Larondelle Y., Van Peteghem C., Huyghebert A. 2004. Chemical safety of conventionally and organically produced foodstuff: a tentative comparison under Belgian conditions. Food Control, 17:14-21.

Pussemier L., Pie Rard J.-Y., Anselme M., Tangni E.K., Motte J.-C., Larondelle Y. 2006. Development and application of analytical methods for the determination of mycotoxins in organic and conventional wheat Food Additives and Contaminants, 23, 11:1208-1218.

Quaranta F., Belocchi A., Camerini M., D’Egidio M.G., Fornara M., Melloni S. 2008. Le varietà per il grano duro bio. Risultati del $6^{\circ}$ anno di prove. L'Informatore Agrario, 64, 37:66-71.

Rocha O., Ansari K., Doohan F.M. 2005. Effects of trichothecene mycotoxins on eukaryotic cells: A review. Food Additives and Contaminants, 22:369-378.

Rossi F., Bertuzzi T., Comizzoli S., Turconi G., Roggi C., Pagani M., Cravedi P., Pietri A. 2006. Preliminary survey on composition and quality of conventional and organic wheat. Ital. J. Food Sci., 4, 18:355-366.

Schollenberger M., Jara H.T., Suchy S., Drochner W., Muller H.M. 2002. Fusarium toxins in wheat flour collected in an area in southwest Germany. Int $\mathrm{J}$ Food Microbiol., 72:85-89.

Schroeder H.W., Christensen J.J. 1963. Factors affecting resistance of wheat to scab caused by Gibberella zeae. Phytopathology, 53:831-838.

Sutton J.C. 1982. Epidemiology of wheat head blight and maize ear rot caused by Fusarium graminearum. Can. J. Plant Pathology, 4:195-209.

Tamm L., Thurig B. 2002. FiBL position papers: mycotoxins in organic food. Ecology and Farming, 4.

Trenholm H.L., Prelusky D.B., Young J.C., Miller J.D. 1989. A Practical Guide to the Prevention of Fusarium Mycotoxins in Grain and Animal Feedstuffs Archives of Environmental Contamination and Toxicology, 18:443-451.

Vànovà M., Klem K., Mìsa P., Matusinsky P., Hajslova J., Lancova K. 2008. The content of Fusarium mycotoxins, grain yield and quality of winter wheat cultivars under organic and conventional cropping system. Plant Soil Environ., 54:395-402.

Wong L.S.L., Tekauz A., Leslie D., Abramson D., McKenzie R.I.H. 1992. Prevalence, distribution and importance of Fusarium head blight in wheat in Manitoba. Canadian Journal of Plant Pathology, 14:233-238. 
Acknowledgements: the authors acknowledge Marcello Guiducci and Andrea Onofri (University of Perugia); Giuliano Mazzieri (ASSAM, Marche); Antonella Petrini and Donatella Fuselli (CERMIS, Tolentino - MC); Pasquale Codianni (CRA-CER, Foggia); Gaetano Amato and Giuseppe Di Prima (University of Palermo) for carring out the field trials. 